\title{
Epidemiological parameter changes of global Avian Influenza H5N1 over two decades, from 1997 to 2017
}

\author{
Ramanad M Haji \\ Community Health Dept, \\ Technical College of Health, \\ Sulaimani Polytechnic University, \\ Sulaimani, Iraq \\ ramand.haji@spu.edu.iq
}

\author{
Muhammed Babakir-Mina \\ Med. Lab. Dept, \\ Technical College of Health, \\ Sulaimani Polytechnic University, \\ Sulaimani, Iraq \\ babakir-mina@spu.edu.iq
}

\author{
Mohammed I M Gubari \\ Community Health Dept, \\ Technical College of Health, \\ Sulaimani Polytechnic University, \\ Sulaimani, Iraq \\ mohammed.gubari@spu.edu.iq
}

\begin{abstract}
Influenza virus (H5N1) is highly contagious disease, which attacks the respiratory tract in humans. The deaths of six people in Hong Kong in 1997 from an H5N1 virus infection was the first indication that a purely avian influenza virus could cause respiratory disease and death in human. The aim of current study was to observe changes of epidemiological parameters of the infected patients, and the behaviour of virus outbreak over two decades of avian influenza virus (H5N1) from 1997 to April 2017. Data of the current study was obtained from WHO (World Health Organization) daily outbreak reports and then computerized and analyzed. It included 826 cases from 1997 to last case in April 2017 for this study. Most of the studied cases, their ages were less than 16 years $(n=366)$, and spread in 16 countries, the top three countries prevalence were Egypt $(n=356)$, Indonesia $(n=175)$, and Vietnam $(n=87)$ respectively. The most years of cases incidence were $2015(n=147)$ and 2006 $(n=122)$. Most of cases were recorded in January $(n=180)$, February (n=149), and March (n=143) respectively. Case fatality rates were $50.7 \%$. In conclusion most cases were in second decade than first decade of (H5N1) outbreak, but death were more in first decade, Also most cases were in low temperature seasons and in very young children but death were more in adults. In first decade, morbidity were more in Asia countries like China, Vietnam, and Indonesia but in second decade, mortality were more in North Africa (Egypt). However, cases were more in Egypt than Indonesia but deaths were more in Indonesia. H5N1 virus must be currently studied and its controlling is highly requested.
\end{abstract}

Keywords: Avian influenza, (H5N1), Epidemiological parameter, Global Avian Influenza, Bird influenza, 1997 to 2017 and H5N1 influenza.

\section{INTRODUCTION}

Influenza is refered to illness caused by influenza virus with symptoms fever, cough, pain, chills, and sore throat, it is severity different from typical flu to life threating pneumonia with other infection like bacterial infection may cause death to infected patient. Influenza viruses negative-strand RNA viruses belong to genus Orthomyxovirus, which consists of three main species A, $B$, and $C$ [1], classification of these viruses are based on the antigenic characteristics of the M protein of the virus envelope and the nucleoprotein within the viral particles, Influenza A viruses are classified on the basis of the antigenic properties of their haemagglutinin (HA) and their neuraminidase (NA) surface glycoproteins[2], to date 16HA (H1-H16) and 9NA (N1-N9) subtypes have been identified, which most of them founded in wild and domestic birds the majority in combinations (e.g. H1N1, H3N2, and etc).[3], All influenza A virus subtypes isolated from 100 bird species and also major mammals species, like pigs, horses, cats, humans and marine mammals[2], most influenza A viruses called low pathogenic avian influenza (LPAI) for poultry, because they cause mild disease poultry. Except H9N2 infection, which cause major problems in poultry in extended areas, they change to highly pathogenic avian influenza (HPAI) in domestic poultry with $100 \%$ mortality rate of the $16 \mathrm{HA}$ subtypes only $\mathrm{H} 5$ and $\mathrm{H} 7$ phenotype it cause by insertion of multiple basic amino acid residues in the HA cleavage site, systematic replication of these viruses cause outbreak in domestic poultry [4], this outbreaks is well known in domestic poultry over decades. Waterfowl is the natural reservoir of all influenza A viruses, usually carrying the infection with no sign of disease[5], with direct or indirect contact with domestic animals (equine, swine, avian) Then transfer to human through direct or indirect contact with this domestic animals [4], other influenza types, B and $\mathrm{C}$, do not affect domestic animals.

Influenza epidemics or pandemic have been recorded throughout history, one of most important influenza virus is highly contagious zoonotic avian influenza virus A (H5N1) diseases, which attack the respiratory tract in humans, like throat and lungs. The deaths of 6 people in Hong Kong in 1997 from an HPAI H5N1 virus infection was the first indication that a purely avian influenza virus could cause respiratory disease and death in human.[6]. Aim of the current study is to observe changes of epidemiological parameters of the infected patients, and the behaviour of virus outbreak over two decades of avian influenza virus (H5N1) from 1997 to April 2017. We emphasize on the demographical characteristics of the patients, severity of disease and regional pattern of human $\mathrm{H} 5 \mathrm{~N} 1$ cases.

\section{METHODS AND MATERIALS}

Data of the current study was obtained from WHO (world health organization) daily outbreak report, 859 cases were recorded from 2003 to 2017 (WHO/GIP, data in HQ as of 16 May 2017), plus 18 cases in May 1997 in Hong-Kong. Cases were excluded if (his/her) epidemiological data or information were not available; in total, it was included 826 cases from 1997 to last case in April 2017 for this review, and onset date of illness obtained for date of illness. Data of the current study was analysed using SPSS (Statistical Package for the Social 
Sciences) version22. Descriptive statistic including mean, standard deviation, frequency and percentage were calculated. In addition, the association between the categorical variable was determined using Chi square test. $\mathrm{P}$ value less than 0.05 was considered significant. Endnote version 7.5 was used for arrangement of the references.

\section{RESULTS}

The current study included 826 cases, were 344 cases in first decade from 1997 to 2007 and 482 cases in second decade from 2008 to 2017, with Mean \pm SD of age $(19.96 \pm 15.87)$. Most of studied cases, their age were less than 16 years $(n=366)$, age range $16-31$ years old comes as the second $(n=256)$ heights percentage of age range among the cases followed by age range 32-47 years old $(n=161)$, age range $48-63$ years old $(n=29)$, more than 63 years old $(n=10)$ respectively with 4 missing their age Figure 1.

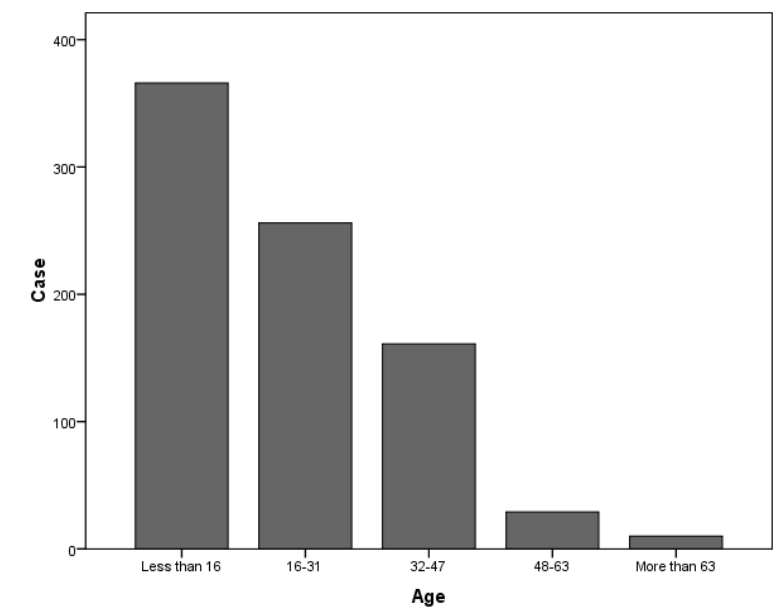

Figure 1 Frequency of age groups

Female patients were highest percentage $54.16 \%$ $(\mathrm{n}=375)$ than male patients among standard group 45.84 $\%(\mathrm{n}=443)$, with 8 gender missing cases Figure 2.

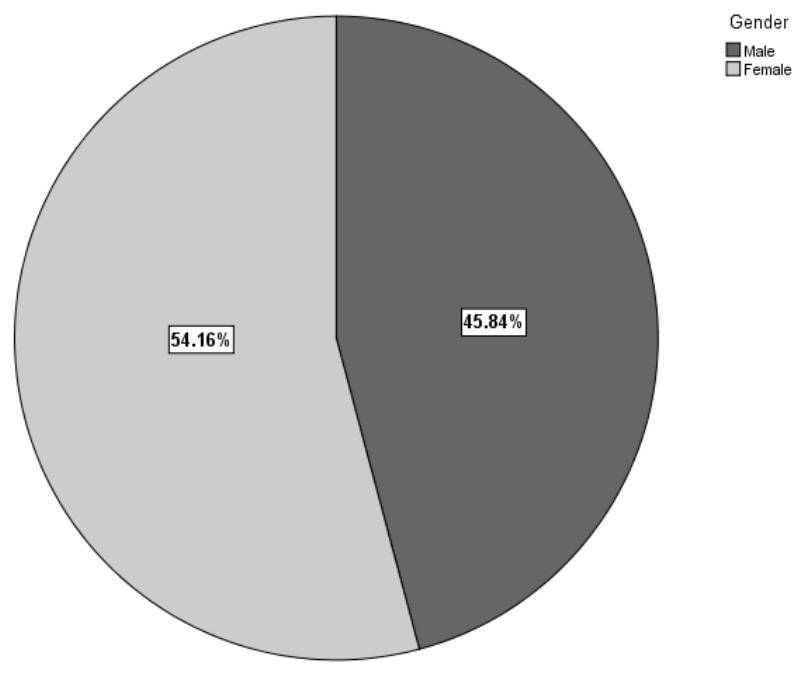

Figure 2 Percentage of gender of ceases

Cases spread in 16 countries, top prevalence three were in Egypt $(n=356)$ cases, Indonesia $(n=175)$ cases and Vietnam $(n=87)$ respectively Figure 3.

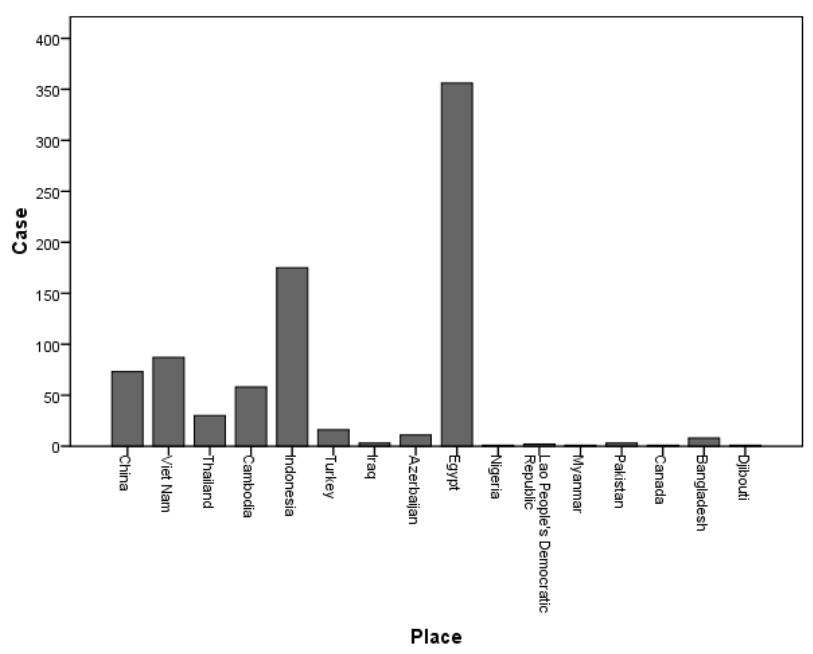

Figure 3 Frequency of countries were H5N1 cases recorded

From the first outbreak in 1997 to last case in 2017 were most cases incidence recorded in $2015(n=147)$ cases, and $2006(n=122)$ cases Figure 4.

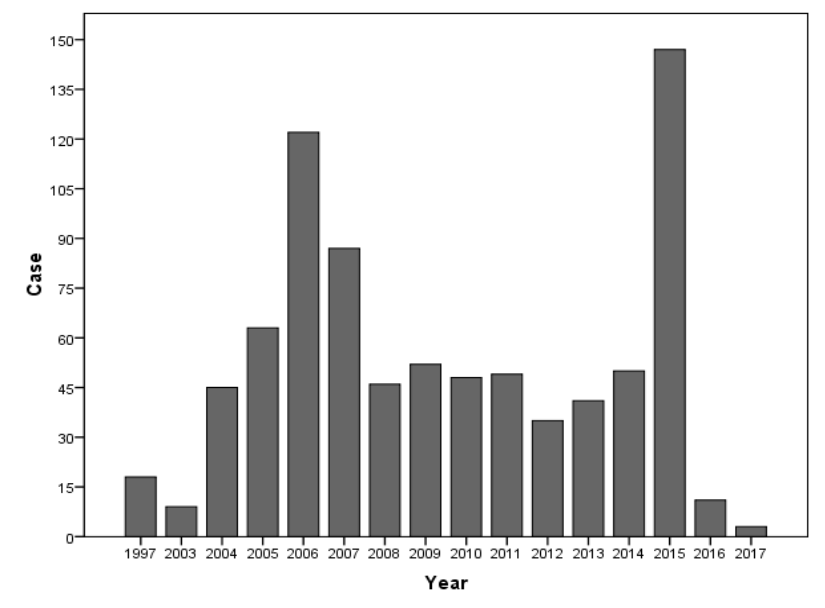

Figure 4 Frequncy of cases in each year from 1997 to 2017

Most of cases were in low temperature season autumn and winter from November to March, especially in January $(n=180)$ cases, February $(n=149)$ cases and March ( $n=143)$ cases respectively Figure 5 and Table 2. 


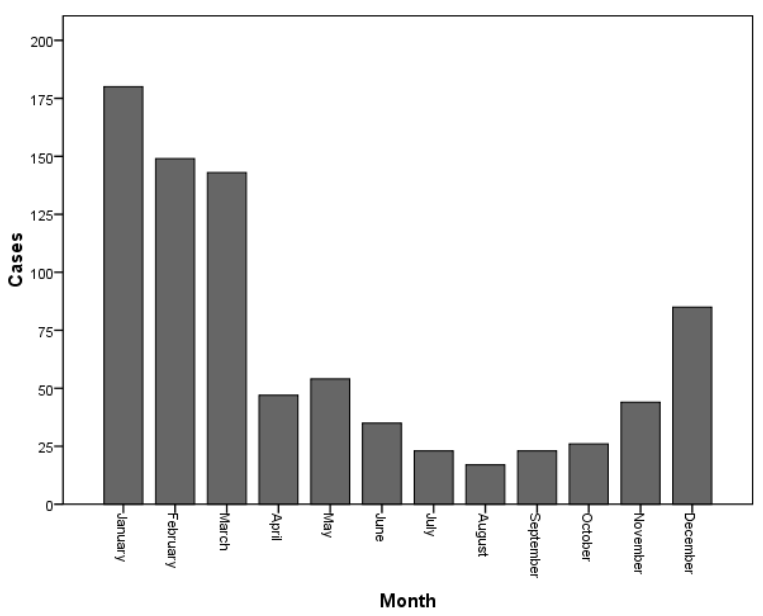

Figure 5 Frequency of H5N1 cases in each month

Death cases $(n=418)$ were more than recovery cases $(n=$ 407), with case fatality rate $50.7 \%$, with one unknown outcome Figure 6.

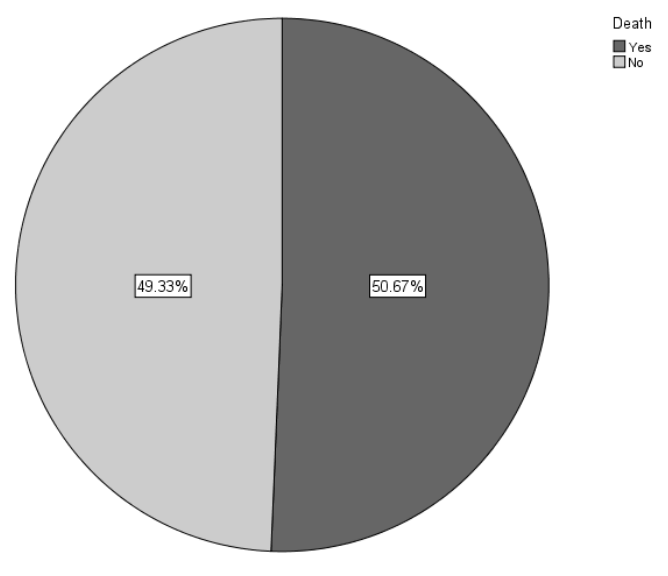

Figure 6 Percentage of death and recover cases

Mortality were more in first decade of outbreak, death were $(n=220)$ cases and recover $(n=123)$ cases with 1 outcome missing from 1997 to 2007 but in second decade from 2008 to 2017 death were $(n=198)$ cases and recover were $(n=284)$ cases, in 2006 were death at peak $(n=82)$ cases but after that number of recovered cases especially in $2015(n=110)$ cases were more than death cases Figure (7). In addition, there was highly significant relation between cases in each year with number of death cases and recover cases with $\mathrm{p}$ value $(0.0001)$.

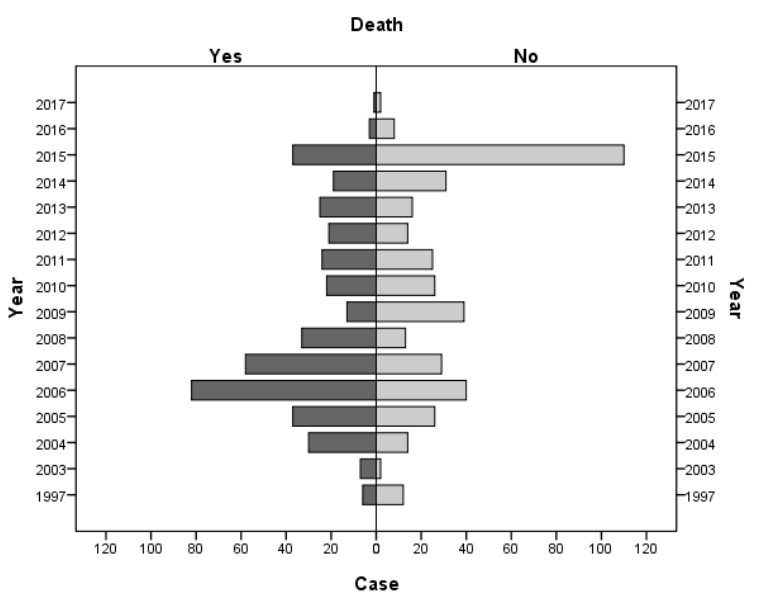

Figure 7 comparison of death and recover cases with cases in each year

Most of cases were at low temperature seasons (autumn, summer and spring) but death number in January $(\mathrm{n}=97)$ cases were at peak comparison to other months February $(n=64)$ cases and March $(n=60)$ cases Figure 8.

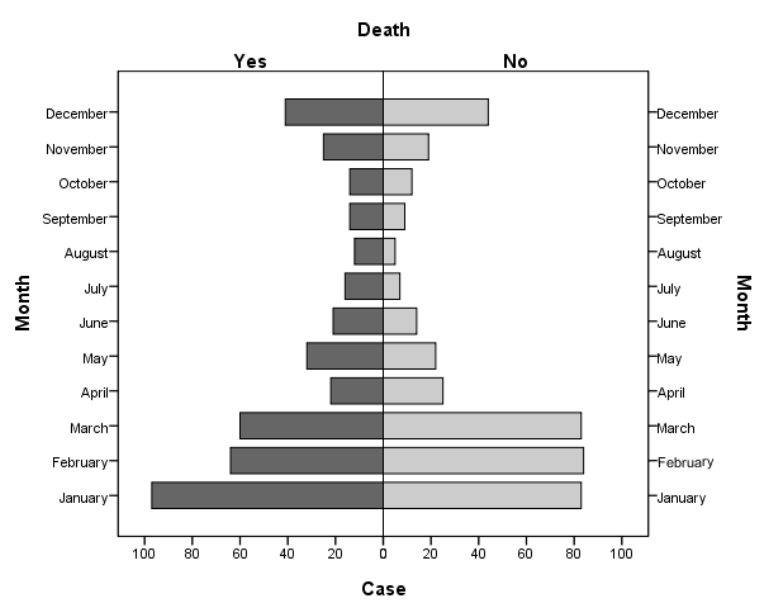

Figure 8 Comparison of death and recover cases with cases in each year

Most of cases were in Egypt $(n=356)$ cases if compared with Indonesia cases were less $(n=175)$ cases but mortality in Indonesia $(n=144)$ cases were more than Egypt $(\mathrm{n}=106)$ cases, after that Vietnam death were $(\mathrm{n}=$ 52) cases respectively, but in China were death $(n=37)$ cases and recover $(n=36)$ nearly same Figure (9). In addition, there was highly significant relation between cases in each country with number of death cases and recover cases with $\mathrm{p}$ value $(0.0001)$. 


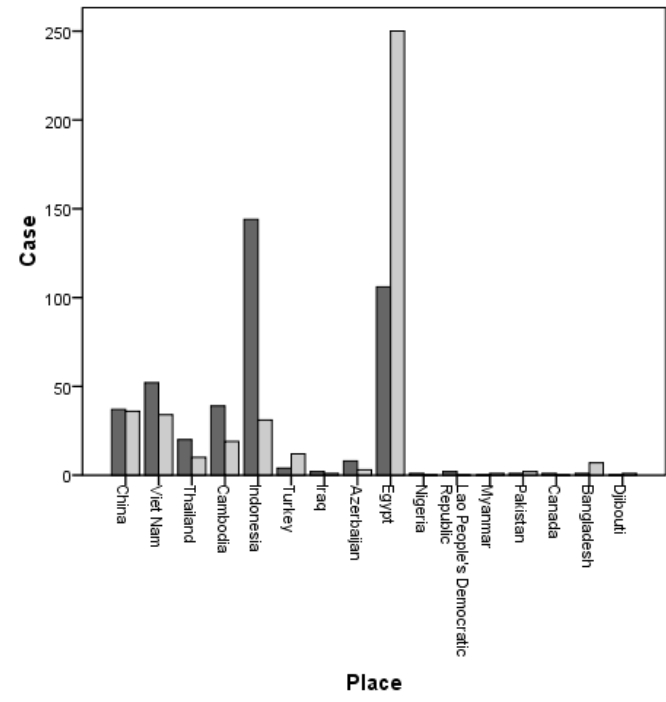

Figure 9 Comparison of death and recover cases with cases in each country

In table 1 were highest incidence cases frequency in each year highlighted, will notice how outbreak changed in each country over two decades, in first decade from 1997 to 2007 were highest incidence of disease were in Asia countries like China, Vietnam and Indonesia respectively but in second decade were in north Africa (Egypt) from 2008 to 2017 except in 2013 were in Indonesia. (Appendix)

In table 3 were highest number of cases highlighted in each months, it show every country in which month were highest number of cases was, January were most repeated month in 7 different countries then March repeated month in 3 different countries. (Appendix)

\section{DISCUSSION}

We collected 826 human infected cases of avian influenza (H5N1) from world health organization (WHO) daily or weekly report over two decades from 1997 to April 2017, cases has been analysed to compare changes of avian influenza (H5N1) effects on human patients in first decade from 1997 to 2008 and in second decade from 2008 to 2017. We found major changes especially in incidence and mortality of avian influenza H5N1 cases.

In this study, most of cases were seen in children and young adults, in addition they have high recover rate than rest of groups. However, mortality rate were higher in adults [7], this might related to virus immunological reaction in different age groups.[8-10], The spread of avian influenza (H5N1) virus over sixteen countries from East Asia to west Asia and North Africa might related to global bird season's migration. [11, 12] Therefore, increasing virus spread range and outbreaks among birds might increase the risk of human exposure [13]. Incidence were more in low temperature seasons (autumn and winter), started from November to March. This could related to activity of wild birds migration and virus activity in low temperature seasons. In the study of 2015 in Asia were found that a closely association between bird migration networks in Asia and time of H5N1 outbreaks [14]. Furthermore, Asia and North Africa's low temperature in winter with cold and dry weather (especially January and February) increase poultry outbreaks and $\mathrm{H} 5 \mathrm{~N} 1$ transmission, this lead increase of human infection. [15-19]. Increasing the incidence of human cases in Egypt in second decade and unique increase incidence since November 2014 [20-22], can be regarded to mixture of some factors, including lower public health awareness of risks in Egypt and seasonal factors like cold weather and possible longer survival of the viruses in the environment [23]. which increase circulation of influenza $\mathrm{H} 5 \mathrm{~N} 1$ viruses in poultry, such as primitive closer to poultry because of cold weather. An increase number of animal to human infection recorded during November 2014 to April 2015 more than all cases from 2006 to 2015[21]. However, the increased numbers of human cases in Egypt are of major concern because of the continued potential pandemic threat from H5N1. However, the prevalence of H5N1 were high in Egypt compare with other country like Indonesia, Vietnam, China, Cambodia and Thailand but mortality was lower in Egypt, it might related to earlier hospital admission, earlier identification and early treatment with Oseltamivir, less severe clinical disease, and less virulent virus clade, [21, 24, 25]. Mortality were more in first decade than second decade even so cases in second decade was more than first decade, This might related to public health awareness, earlier identification and use of antiviral drug oseltamivir. Oseltamivir can reduce the severity of illness and mortality when started soon after symptom onset and appears to benefit all age groups. Therefore, it should be considered for all H5N1 cases [26-28], and many affected countries has implemented vaccination for domestic poultry to control $\mathrm{H} 5 \mathrm{~N} 1$ in poultry, especially in countries where influenza $\mathrm{H} 5 \mathrm{~N} 1$ viruses have become enzootic in poultry and wild birds.[29, 30].

Limitations of this study: there has been some limitation in this study, all data collected from WHO daily report which some data could missed or not reported or part of case information were missing like date of illness, gender, age of patients and outcome. Those cases with unavailable or not reported characteristic information has been excluded especially from Vietnam were most of cases diagnosed with H5N1 virus after patient's death especially in early years of outbreak.

\section{CONCLUSION}

Most cases were in second decade compare to first decade of avian influenza (H5N1) outbreak but death were more in first decade. In addition, most cases were in low temperature seasons from November to March but in January was the most repeated month among different countries. Furthermore, most cases were in very young children, but death were more in adults. In first decade, morbidity were more in Asia countries like China, Vietnam, and Indonesia but in second decade, morbidity were more in North Africa (Egypt). However, 
cases were more in Egypt than Indonesia but death were more in Indonesia. Cases were more in female than male also death were more in female, with case fatality rate $50.7 \%$ for all cases.

\section{REFERENCE}

[1] I. Stephenson and J. Democratis, "Influenza: current threat from avian influenza," $\mathrm{Br} \mathrm{Med}$ Bull, vol. 75-76, pp. 63-80, 2005.

[2] N. Cox, F. Fuller, N. Kaverin, H. Klenk, R. Lamb, B. Mahy, et al., "Orthomyxoviridae," Virus taxonomy. Seventh report of the international committee on taxonomy of viruses, pp. 585-597, 2000.

[3] R. A. Fouchier, V. Munster, A. Wallensten, T. M. Bestebroer, S. Herfst, D. Smith, et al., "Characterization of a novel influenza A virus hemagglutinin subtype (H16) obtained from black-headed gulls," Journal of virology, vol. 79, pp. 2814-2822, 2005.

[4] D. J. Alexander, "An overview of the epidemiology of avian influenza," Vaccine, vol. 25, pp. 5637-5644, 2007.

[5] K. M. Sturm-Ramirez, D. J. Hulse-Post, E. A. Govorkova, J. Humberd, P. Seiler, P. Puthavathana, et al., "Are ducks contributing to the endemicity of highly pathogenic H5N1 influenza virus in Asia?," J Virol, vol. 79, pp. 11269-79, Sep 2005.

[6] E. C. Claas, A. D. Osterhaus, R. Van Beek, J. C. De Jong, G. F. Rimmelzwaan, D. A. Senne, et al., "Human influenza A H5N1 virus related to a highly pathogenic avian influenza virus," The Lancet, vol. 351, pp. 472-477, 1998.

[7] S. Lai, Y. Qin, B. J. Cowling, X. Ren, N. A. Wardrop, M. Gilbert, et al., "Global epidemiology of avian influenza A H5N1 virus infection in humans, 1997-2015: a systematic review of individual case data," The Lancet Infectious Diseases, vol. 16, pp. e108-e118, 2016.

[8] T. M. Uyeki, "Global epidemiology of human infections with highly pathogenic avian influenza A (H5N1) viruses," Respirology, vol. 13, 2008.

[9] "Human cases of influenza at the human-animal interface, 2013," Wkly Epidemiol Rec, vol. 89, pp. 309-20, Jul 112014.

[10] WHO. (2 March 2017, 19 July). Antigenic and genetic characteristics of zoonotic influenza viruses and candidate vaccine viruses developed for potential use in human vaccines, September 2015. Available: http://www.who.int/entity/influenza/vaccines/vi rus/201509 zoonotic vaccinevirusupdate.pdf?u $\underline{\mathrm{a}=1}$
[11] G. Smith, T. Naipospos, T. Nguyen, M. De Jong, D. Vijaykrishna, T. Usman, et al., "Evolution and adaptation of H5N1 influenza virus in avian and human hosts in Indonesia and Vietnam," Virology, vol. 350, pp. 258-268, 2006.

[12] M. T. Le, H. F. Wertheim, H. D. Nguyen, W. Taylor, P. V. Hoang, C. D. Vuong, et al., "Influenza A H5N1 clade 2.3. 4 virus with a different antiviral susceptibility profile replaced clade 1 virus in humans in northern Vietnam," PloS one, vol. 3, p. e3339, 2008.

[13] L.-Q. Fang, S. J. de Vlas, S. Liang, C. W. Looman, P. Gong, B. $\mathrm{Xu}$, et al., "Environmental factors contributing to the spread of H5N1 avian influenza in mainland China," PloS one, vol. 3, p. e2268, 2008.

[14] H. Tian, S. Zhou, L. Dong, T. P. Van Boeckel, Y. Cui, S. H. Newman, et al., "Avian influenza H5N1 viral and bird migration networks in Asia," Proceedings of the National Academy of Sciences, vol. 112, pp. 172-177, 2015.

[15] L. O. Durand, P. Glew, D. Gross, M. Kasper, S. Trock, I. K. Kim, et al., "Timing of influenza A (H5N1) in poultry and humans and seasonal influenza activity worldwide, 2004-2013," Emerging infectious diseases, vol. 21, p. 202, 2015.

[16] X. Li, Z. Zhang, A. Yu, S. Y. Ho, M. J. Carr, W. Zheng, et al., "Global and local persistence of influenza A (H5N1) virus," Emerging infectious diseases, vol. 20, p. 1287, 2014.

[17] M. B. Mathur, R. B. Patel, M. Gould, T. M. Uyeki, J. Bhattacharya, Y. Xiao, et al., "Seasonal patterns in human A (H5N1) virus infection: analysis of global cases," PLoS One, vol. 9, p. e106171, 2014.

[18] K. Chaichoune, W. Wiriyarat, A. Thitithanyanont, R. Phonarknguen, L. Sariya, S. Suwanpakdee, et al., "Indigenous sources of 2007-2008 H5N1 avian influenza outbreaks in Thailand," Journal of General Virology, vol. 90, pp. 216-222, 2009.

[19] P. M. Rabinowitz, D. Galusha, S. Vegso, J. Michalove, S. Rinne, M. Scotch, et al., "Comparison of human and animal surveillance data for H5N1 influenza A in Egypt 20062011," PloS one, vol. 7, p. e43851, 2012.

[20] S. Refaey, E. Azziz-Baumgartner, M. M. Amin, M. Fahim, K. Roguski, H. A. E. A. Elaziz, et al., "Increased number of human cases of influenza virus A (H5N1) infection, Egypt, 2014-15," Emerging infectious diseases, vol. 21, p. 2171, 2015

[21] "Human cases of influenza at the human-animal interface, January 2014-April 2015," Wkly 
Epidemiol Rec, vol. 90, pp. 349-62, Jul 10 2015.

[22] WHO. (09 April 2015, 19 July). Avian influenza A(H5N1) in Egypt, 9 April 2015. Available:

http://www.emro.who.int/surveillanceforecasting-response/surveillance-news/avianinfluenza-ah5n1-in-egypt-9-april-2015.html

[23] WHO. (3 March 2015, 19 July). Influenza at the human-animal interface: summary and assessment as of 3 March 2015. Available: http://www.who.int/entity/influenza/human_ani mal_interface/Influenza_Summary_IRA_HA_i nterface_3_March_2015.pdf?ua=1

[24] A. Kandeel, S. Manoncourt, E. A. el Kareem, A.-N. M. Ahmed, S. El-Refaie, H. Essmat, et al., "Zoonotic transmission of avian influenza virus (H5N1), Egypt, 2006-2009," Emerging infectious diseases, vol. 16, p. 1101, 2010.

[25] R. B. Patel, M. B. Mathur, M. Gould, T. M. Uyeki, J. Bhattacharya, Y. Xiao, et al., "Demographic and clinical predictors of mortality from highly pathogenic avian influenza A (H5N1) virus infection: CART analysis of international cases," PLoS One, vol. 9, p. e91630, 2014.

[26] W. Adisasmito, P. K. S. Chan, N. Lee, A. F. Oner, V. Gasimov, F. Aghayev, et al., "Effectiveness of antiviral treatment in human influenza A (H5N1) infections: analysis of a Global Patient Registry," The Journal of infectious diseases, vol. 202, pp. 1154-1160, 2010.

[27] P. K. Chan, N. Lee, M. Zaman, W. Adisasmito, R. Coker, W. Hanshaoworakul, et al., "Determinants of antiviral effectiveness in influenza virus A subtype H5N1," The Journal of infectious diseases, vol. 206, pp. 1359-1366, 2012.

[28] WHO. (15 August 2007, 19 July). Clinical management of human infection with avian infl uenza A (H5N1) virus. Aug 15, 2007. Available: http://www.who.int/influenza/resources/docum ents/clinical_management_h5n1_15_08_2007/e $\underline{\mathrm{n} /}$

[29] D. Swayne, G. Pavade, K. Hamilton, B. Vallat, and K. Miyagishima, "Assessment of national strategies for control of high-pathogenicity avian influenza and low-pathogenicity notifiable avian influenza in poultry, with emphasis on vaccines and vaccination," Revue Scientifique et Technique-OIE, vol. 30, p. 839, 2011.

[30] C. Li, Z. Bu, and H. Chen, "Avian influenza vaccines against $\mathrm{H} 5 \mathrm{~N} 1$ 'bird flu'," Trends in biotechnology, vol. 32, pp. 147-156, 2014.

\section{Biography}

Ramanad M Haji:

https://scholar.google.com/citations?user=Z9BPisoA

AAAJ\&hl=en

Muhammed Babakir-Mina:

https://scholar.google.com/citations?user=X5P08_EA

AAAJ\&hl=en

Mohammed I M Gubari:

https://scholar.google.com/citations?user=7LMGRg4

AAAAJ\&hl=en 
Supportive tables

Table 1: Comparison of cases in each countries with cases in each year from 1997 to 2017 , highest incidence cases frequency in each year highlighted

\begin{tabular}{|c|c|c|c|c|c|c|c|c|c|c|c|c|c|c|c|c|}
\hline \multirow{2}{*}{ Place } & \multicolumn{16}{|c|}{ Year } \\
\hline & 1997 & 2003 & 2004 & 2005 & 2006 & 2007 & 2008 & 2009 & 2010 & 2011 & 2012 & 2013 & 2014 & 2015 & 2016 & 2017 \\
\hline China & 18 & 4 & 0 & 8 & 13 & 5 & 4 & 7 & 2 & 0 & 2 & 2 & 2 & 5 & 1 & 0 \\
\hline Viet Nam & 0 & 5 & 23 & 26 & 0 & 8 & 4 & 6 & 7 & 0 & 4 & 2 & 2 & 0 & 0 & 0 \\
\hline Thailand & 0 & 0 & 22 & 5 & 3 & 0 & 0 & 0 & 0 & 0 & 0 & 0 & 0 & 0 & 0 & 0 \\
\hline Cambodia & 0 & 0 & 0 & 4 & 2 & 1 & 1 & 1 & 1 & 8 & 3 & 28 & 9 & 0 & 0 & 0 \\
\hline Indonesia & 0 & 0 & 0 & 20 & 55 & 42 & 26 & 0 & 8 & 6 & 11 & 3 & 2 & 2 & 0 & 0 \\
\hline Turkey & 0 & 0 & 0 & 0 & 16 & 0 & 0 & 0 & 0 & 0 & 0 & 0 & 0 & 0 & 0 & 0 \\
\hline Iraq & 0 & 0 & 0 & 0 & 3 & 0 & 0 & 0 & 0 & 0 & 0 & 0 & 0 & 0 & 0 & 0 \\
\hline Azerbaijan & 0 & 0 & 0 & 0 & 11 & 0 & 0 & 0 & 0 & 0 & 0 & 0 & 0 & 0 & 0 & 0 \\
\hline Egypt & 0 & 0 & 0 & 0 & 18 & 26 & 8 & 38 & 30 & 33 & 12 & 4 & 35 & 139 & 10 & 3 \\
\hline Nigeria & 0 & 0 & 0 & 0 & 0 & 1 & 0 & 0 & 0 & 0 & 0 & 0 & 0 & 0 & 0 & 0 \\
\hline $\begin{array}{c}\text { Lao People's } \\
\text { Democratic } \\
\text { Republic }\end{array}$ & 0 & 0 & 0 & 0 & 0 & 2 & 0 & 0 & 0 & 0 & 0 & 0 & 0 & 0 & 0 & 0 \\
\hline Myanmar & 0 & 0 & 0 & 0 & 0 & 1 & 0 & 0 & 0 & 0 & 0 & 0 & 0 & 0 & 0 & 0 \\
\hline Pakistan & 0 & 0 & 0 & 0 & 0 & 1 & 2 & 0 & 0 & 0 & 0 & 0 & 0 & 0 & 0 & 0 \\
\hline Canada & 0 & 0 & 0 & 0 & 0 & 0 & 0 & 0 & 0 & 0 & 0 & 1 & 0 & 0 & 0 & 0 \\
\hline Bangladesh & 0 & 0 & 0 & 0 & 0 & 0 & 1 & 0 & 0 & 2 & 3 & 1 & 0 & 1 & 0 & 0 \\
\hline Djibouti & 0 & 0 & 0 & 0 & 1 & 0 & 0 & 0 & 0 & 0 & 0 & 0 & 0 & 0 & 0 & 0 \\
\hline
\end{tabular}


Table 2: Comparison of cases in all months with cases in each year from 1997 to 2017, highest incidence cases frequency in each year highlighted

\begin{tabular}{|c|c|c|c|c|c|c|c|c|c|c|c|c|c|c|c|c|}
\hline \multirow{2}{*}{ Month } & \multicolumn{16}{|c|}{ Year } \\
\hline & 1997 & 2003 & 2004 & 2005 & 2006 & 2007 & 2008 & 2009 & 2010 & 2011 & 2012 & 2013 & 2014 & 2015 & 2016 & 2017 \\
\hline January & 0 & 0 & 19 & 11 & 27 & 11 & 12 & 11 & 9 & 7 & 8 & 12 & 6 & 47 & 0 & 0 \\
\hline February & 0 & 2 & 12 & 4 & 12 & 8 & 11 & 4 & 10 & 10 & 10 & 5 & 5 & 52 & 2 & 2 \\
\hline March & 0 & 0 & 3 & 6 & 20 & 23 & 6 & 8 & 8 & 16 & 8 & 3 & 4 & 36 & 2 & 0 \\
\hline April & 0 & 0 & 0 & 6 & 10 & 2 & 3 & 6 & 3 & 5 & 3 & 3 & 1 & 4 & 0 & 1 \\
\hline May & 1 & 0 & 0 & 0 & 21 & 7 & 2 & 10 & 2 & 6 & 2 & 0 & 0 & 0 & 3 & 0 \\
\hline June & 0 & 0 & 0 & 1 & 9 & 8 & 0 & 3 & 1 & 1 & 1 & 3 & 2 & 4 & 2 & 0 \\
\hline July & 0 & 0 & 0 & 2 & 5 & 3 & 2 & 2 & 2 & 2 & 1 & 3 & 0 & 0 & 1 & 0 \\
\hline August & 0 & 0 & 3 & 0 & 3 & 4 & 0 & 2 & 3 & 1 & 0 & 1 & 0 & 0 & 0 & 0 \\
\hline September & 0 & 0 & 4 & 4 & 5 & 2 & 0 & 2 & 1 & 1 & 0 & 3 & 1 & 0 & 0 & 0 \\
\hline October & 0 & 0 & 1 & 10 & 3 & 5 & 1 & 0 & 0 & 0 & 0 & 5 & 0 & 1 & 0 & 0 \\
\hline November & 4 & 2 & 0 & 10 & 2 & 3 & 4 & 2 & 3 & 0 & 1 & 2 & 10 & 0 & 1 & 0 \\
\hline December & 13 & 5 & 3 & 9 & 5 & 11 & 5 & 2 & 6 & 0 & 1 & 1 & 21 & 3 & 0 & 0 \\
\hline
\end{tabular}


Table 3: Comparison of cases in all months with cases in each country, highest incidence cases frequency in each month highlighted

\begin{tabular}{|c|c|c|c|c|c|c|c|c|c|c|c|c|c|c|c|c|}
\hline \multirow[b]{2}{*}{ Month } & \multicolumn{16}{|c|}{ Place } \\
\hline & China & $\begin{array}{l}\text { Viet } \\
\text { Nam }\end{array}$ & Thailand & Cambodia & Indonesia & Turkey & Iraq & Azerbaijan & Egypt & Nigeria & $\begin{array}{c}\text { Lao } \\
\text { People's } \\
\text { Democratic } \\
\text { Republic }\end{array}$ & Myanmar & Pakistan & Canada & Bangladesh & Djibouti \\
\hline January & 13 & 26 & 10 & 17 & 28 & 16 & 2 & 0 & 66 & 1 & 0 & 0 & 0 & 0 & 1 & 0 \\
\hline February & 12 & 19 & 4 & 8 & 17 & 0 & 0 & 4 & 81 & 0 & 2 & 0 & 0 & 0 & 2 & 0 \\
\hline March & 5 & 10 & 3 & 8 & 23 & 0 & 1 & 7 & 82 & 0 & 0 & 0 & 0 & 0 & 4 & 0 \\
\hline April & 2 & 8 & 0 & 5 & 7 & 0 & 0 & 0 & 25 & 0 & 0 & 0 & 0 & 0 & 0 & 0 \\
\hline May & 4 & 3 & 0 & 2 & 24 & 0 & 0 & 0 & 20 & 0 & 0 & 0 & 0 & 0 & 0 & 1 \\
\hline June & 3 & 2 & 1 & 2 & 13 & 0 & 0 & 0 & 14 & 0 & 0 & 0 & 0 & 0 & 0 & 0 \\
\hline July & 0 & 3 & 2 & 4 & 7 & 0 & 0 & 0 & 7 & 0 & 0 & 0 & 0 & 0 & 0 & 0 \\
\hline August & 0 & 3 & 0 & 2 & 8 & 0 & 0 & 0 & 4 & 0 & 0 & 0 & 0 & 0 & 0 & 0 \\
\hline September & 0 & 0 & 4 & 2 & 12 & 0 & 0 & 0 & 5 & 0 & 0 & 0 & 0 & 0 & 0 & 0 \\
\hline October & 2 & 1 & 4 & 5 & 12 & 0 & 0 & 0 & 0 & 0 & 0 & 0 & 1 & 0 & 1 & 0 \\
\hline November & 11 & 2 & 1 & 2 & 13 & 0 & 0 & 0 & 12 & 0 & 0 & 1 & 2 & 0 & 0 & 0 \\
\hline December & 21 & 10 & 1 & 1 & 11 & 0 & 0 & 0 & 40 & 0 & 0 & 0 & 0 & 1 & 0 & 0 \\
\hline
\end{tabular}

